\title{
Punishment and Sovereignty in De Indis and De iure belli ac pacis
}

\author{
Brad Hinshelwood \\ Unaffiliated; Ph.D, Harvard University, 2015 \\ brad.hinshelwood@gmail.com
}

\begin{abstract}
Grotius's theory of punishment provides a unique lens through which to view his evolving thought on sovereignty between De Indis and De iure belli ac pacis and the implications of that evolution for Grotius's theory of the ius in bello. Throughout both works, Grotius attempted to leave open the possibility of private punishment and private warfare, a position not easily squared with prevailing views of sovereign authority. Initially, Grotius was content with a theory marrying the private right of punishment with more traditional Scholastic views of sovereignty through a transfer of the private right from individuals into the hands of the sovereign. This theory also adopted traditional views of subject responsibility for sovereign acts-and, by extension, the exposure of subjects to punishment for the acts of their sovereign. By the time of his mature work, however, Grotius turned away from natural law justifications for collective responsibility and collective punishment, denying that subjects had to answer for the acts of their sovereign as a necessary incident of the compact creating civil society. This led Grotius to refer virtually all forms of collective responsibility, such as reprisal or punishment exacted through war, to the law of nations. This sharp reduction of the natural consequences of the creation of sovereign power also enabled Grotius's argument that the private right of war, and in particular the private right of punishment, remained available after the creation of civil society.
\end{abstract}

\section{Keywords}

punishment - sovereignty - punitive war - reprisal - ius in bello - natural law 
Hugo Grotius's De Indis has won notoriety for its innovative claim that individuals hold a private right of punishment prior to the institution of civil society. This highly original argument has drawn attention in particular because of its implications for Grotius's views on colonialism and colonial expansion, ${ }^{1}$ and has been hailed as 'a major innovation in legal theory and practice' 2 and the 'vital move' in Grotius's account. ${ }^{3}$ Less studied, however, has been the closely related and equally important question of how this conception of private authority interacts with Grotius's theory of sovereignty. Offering a theory of private punishment required Grotius to revise the traditional view that punitive authority was held exclusively by the state, as well as to explain how the state came to hold a right of punishment compatible with private rights to punish. Yet - at least at the time of De Indis - Grotius did not wish to completely undermine traditional theories of sovereignty, because they also provided grounds for determining which individuals within a state were amenable to punishment for the state's misdeeds, an important element for Grotius in explaining why the Santa Catarina was legitimate prize.

Prior work examining Grotius's theory of sovereignty has noted that there appears to be a shift in his thought between De Indis and De iure belli ac pacis, even referring to it as 'the one feature of [De iure belli ac pacis] which was completely new'. This is particularly true of Grotius's account of the origin of the sovereign's powers. Where De Indis viewed sovereign powers as deriving from a transfer of individually-held rights (including the right to punish) from subjects to the sovereign, De iure belli ac pacis contained no such clear description. The resulting literature on Grotius's new theory of sovereignty has provided a welter of possible explanations to fill this lacuna, drawing from scattered references in Grotius's text. None of these explanations, however, has considered

1 On the general content of Grotius's theory, see Benjamin Straumann, 'The Right to Punish as a Just Cause of War in Hugo Grotius's Natural Law', Studies in the History of Ethics, Feb. 2006, available at http://www.historyofethics.org/o22006/o22006Straumann.shtml. For discussions of the originality and importance of this position, see Martine Julia van Ittersum, Profit and Principle: Hugo Grotius, Natural Rights Theories and the Rise of Dutch Power in the East Indies (Boston: Brill, 2006), p. 29; Richard Tuck, The Rights of War and Peace (New York: Oxford University Press, 1999), p. 81. Tuck also addresses in detail the importance of this position for Grotius's colonial objectives. This aspect of Grotius's theory has been further explored in Gustaaf van Nifterik, 'Grotius and the Origin of the Ruler's Right to Punish', in: Property, Piracy and Punishment, ed. by Hans Blom (Boston: Brill, 2009), pp. 396-416.

2 Van Ittersum, Profit and Principle, p. 29.

3 Tuck, Rights of War and Peace, p. 81.

4 Richard Tuck, Natural Rights Theories (New York: Cambridge University Press, 1979), p. 77. 
the implications of this shift for Grotius's other philosophical commitments around punishment, particularly collective punishment.

Grotius's challenge in De iure belli ac pacis was to provide a theory of sovereignty that accommodated multiple conflicting objectives. Throughout the early 160os, Grotius found himself defending the legitimacy of the Dutch republic in its long-running war of independence, and his theory of sovereignty therefore had to justify the Dutch state. Alongside the land war in Europe, the Dutch launched an aggressive campaign of overseas colonial expansion, funding the revolt and directly challenging Spanish and Portuguese trade monopolies. This led Grotius to think intensely about the possibilities for private participation in public warfare, since the Voc was an ostensibly private body which engaged in warfare against European and Asian states half a world away. De Indis was a direct attempt to grapple with these issues, as Grotius was commissioned by the voc directors to write a defense of the capture of the Santa Catarina. The critical role of the voc in Dutch warfare extended into the 1620 s and beyond, and any theory of sovereignty needed to make room for continued voc involvement. Finally, in De iure belli ac pacis Grotius sought to provide a set of protections for civilians even more expansive than those proposed by prior writers. Grotius thus sought a thin conception of sovereignty: a theory which sharply reduced subject liability for the misdeeds of the state and rejected the state's exclusive authority over violence while accommodating the Dutch revolt.

These objectives were quite difficult to achieve within the range of conceptual options available to Grotius. In De Indis, Grotius married traditional Scholastic thought on sovereignty, particularly arguments drawn from Vitoria, with the novel claim that sovereign powers (and in particular the power to punish) derived their source from the transfer of those rights from the individuals who originally held them to the sovereign. This approach had several key advantages for the limited objectives of De Indis. For one, it opened a theoretical avenue to justify the voc's private warmaking and punishment abroad. Yet it also provided a relatively uncontroversial way to justify the voc's targeting of the Santa Catarina, a vessel which had committed no hostile acts. In sum, because Scholastic thought viewed the sovereign as the agent of the people in exercising sovereign authority, the people could be held responsible for his acts, at least insofar as their property could be seized for restitution or punishment. In this sense, Grotius's claims about the original transfer of the right to punish worked quite harmoniously with the Scholastic vision of agency. Although Grotius lacked a notion of authorization akin to the one present in later contractarian thought, if a sovereign could be said in some sense to exercise individual powers delegated to him when making war, the conceptual connection between sovereign act and subject responsibility was easier to draw. 
By the time of De iure belli ac pacis, however, Grotius was no longer keen to preserve that agency relationship, because that notion made it particularly difficult for Grotius to make the claims to moderation which became central to his account of the ius in bello. The role of the private right of punishment in De iure belli ac pacis is thus sharply reduced, and Grotius never provides an account of the origin of sovereign powers on par with the one articulated in De Indis.

Punishment is a uniquely important lens through which to view Grotius's views on sovereignty both because it is intimately bound up with all of his objectives in both De Indis and De iure belli ac pacis and because punishment already had a long lineage in political thought on the relationship between war and sovereign power. Punishment was accepted as a legitimate justification for war by virtually every writer in both the humanist and Scholastic traditions, so the general claim that punishment was a feature of international relations was not controversial. Yet no one prior to Grotius had tried to argue that public punishment was derived from a private right to punish, and scholars had consistently viewed the right of war-including punitive war-as confined to sovereign powers. ${ }^{5}$ Jean Bodin, for example, listed as his first and most important mark of sovereignty the power to make laws, which itself included the right of punishment up to the penalty of death, and his second mark was the power 'to denounce war, or treat of peace. ${ }^{6}$ Alberico Gentili repeatedly insisted that war is waged only by sovereigns, not by private individuals, and cited approvingly to Augustine for this claim. ${ }^{7}$

The Scholastic tradition was equally emphatic on this point; the first requirement for a just war in Aquinas's account was 'the authority of the sovereign by whose command the war is to be waged'. 8 Francisco Suarez, one of the leading theorists in this tradition, stands as an example of the arguments at play: punishment is a permissible cause of war, but requires that some wrong have been committed. War between nations exists as a substitute for judicial process, which is available to individuals, and the 'jurisdiction' of the just belligerent exists because of the crime of the transgressor, which generates

5 As Tuck notes, 'Grotius made his vital move in a passage discussing the right of punishment, or the ius gladii-the fundamental right to use force, possessed (according to every traditional theorist) by the civil magistrate and only the civil magistrate.' Tuck, Rights of War and Peace, p. 81 .

6 Jean Bodin, Six Books of a Commonweale, trans. Richard Knolles, ed. Kenneth McRae (Cambridge: Harvard University Press, 1962), I.10, pp. 159, 163.

7 See Alberico Gentili, Three Books on the Law of War, trans. John C. Rolfe (Oxford: Clarendon Press, 1933), I.3, p. 15 (citing Augustine); I.7, p. 35 .

8 Thomas Aquinas, Summa Theologica $\mathrm{II}^{\mathrm{a}}-\mathrm{II}{ }^{\mathrm{ae}}$, qu. 40.1 (New York: Benzinger Brothers, 1947). 
superiority. Suarez is at pains to reject the position that 'by a like reasoning, any private person who might be unable to secure such punishment through a judge could take the law into his own hands, executing it on his own authority.' Suarez makes two arguments in response. First, he claims that 'punishment has for its essential purpose not private but public good, and hence it has been committed not to the private individual, but to the public body,' such that if the public is unable to avenge an injury, a subject must endure the loss. Second, individuals can never obtain the jurisdiction which Suarez describes, since 'if they could possess it, there would be no need to employ the public power of jurisdiction; or at least, since this power of jurisdiction is derived from men themselves, each one would have had the power to refrain from transferring it to the state official, retaining it, on the contrary, for himself,' a possibility 'opposed to natural law'. 9

It was this tradition that Grotius set out to upend in De Indis, and Grotius spent much of De iure belli ac pacis refashioning the contours of his theory from his earlier work.

\section{The Scholastic Sympathies of De Indis}

Grotius's justifications for the individual right of punishment are well known and need only brief recapitulation. Grotius is clear that civil society exists in part to provide adjudicatory mechanisms to overcome the bias inherent in acting as judge in one's own case, ${ }^{10}$ and he is adamant that in civil society, the law of nature provides that 'No citizen shall seek to enforce his own right against a fellow citizen, save by judicial procedure.'11 The same holds for conflicts between citizens of different states. ${ }^{12}$ Despite this emphasis on recourse to the judicial process, Grotius made clear that this obligation was dependent on the state's ability to satisfy the basic obligations of protection and reparation under

9 Francisco Suarez, 'On Laws and God the Lawgiver', in Selections from Three Works of Francisco Suarez, trans. Gwladys Williams et al. (Oxford: Clarendon Press, 1944), Disp. 13.4. 5-7, pp. 818-20. See also Onuma Yasuaki, 'War', in: A Normative Approach to War, ed. by Onuma Yasuaki (New York: Oxford University Press, 1993), p. 79.

10 IPC, II, p. 42. All citations to De Indis [IPC] are by chapter and page number to Hugo Grotius, Commentary on the Law of Prize and Booty, trans. Gwladys Williams, ed. Martine Julia van Ittersum (Indianapolis: Liberty Fund, 2006).

11 IPC, II, p. 43.

12 IPC, II, p. 46. 'Neither the state nor any citizen thereof shall seek to enforce his own right against another state or its citizen, save by judicial procedure.' 
natural law. ${ }^{13}$ The only thing that bars a private individual from waging war is the natural law forbidding individuals from enforcing their rights against fellow citizens outside of the judicial process. ${ }^{14}$ Otherwise, individuals are entitled to wage private wars based on the same four causes as justify state conflictself-defense, defense of property, recovery of debts, and 'from wrongdoing, and from every injury ... inflicted with unjust intent'.15 Significantly, the law commanding recourse to the judicial process becomes 'dormant ... when judicial means for the attainment of our rights are defective.' 16 This dormancy can be temporary, as in a case of immediate self-defense, ${ }^{17}$ or can reflect a 'continuous lack of means for judicial settlement,' which occurs 'when in a given place there is no one possessing jurisdiction, a state of affairs which may exist in desert lands, on islands, on the ocean or in any region where the people have no government. ${ }^{\prime 18}$ Similarly, a continuous lack of jurisdiction can exist if the ruler who would have jurisdiction cannot investigate or when his subjects refuse to obey his rulings. ${ }^{19}$

Grotius then turned to how justice should be done in those times of dormancy, beginning with the understated admission that 'since a great many persons maintain that the power to punish has been granted to the state alone (wherefore judgements, too, are [habitually] termed "public"), it might seem that private application of force is ruled out entirely.'20 To justify this, Grotius turns to 'what was permissible for individuals prior to the establishment of states. ${ }^{21}$ This leads Grotius to the crux of the problem:

In the light of the foregoing discussion, it is clear that the causes for the infliction of punishment are natural, and derived from that precept which we have called the First Law. Even so, is not the power to punish essentially a power that pertains to the state? Not at all! On the contrary, just as every right of the magistrate comes to him from the state, so has the same right come to the state from private individuals; and similarly, the power of the state is the result of collective agreement, as we demonstrated in our discussion of the Third Rule. Therefore, since no one

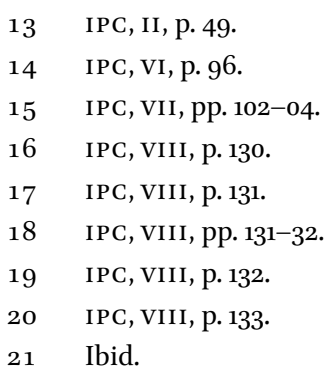


is able to transfer a thing that he never possessed, it is evident that the right of chastisement was held by private persons before it was held by the state. ${ }^{22}$

On this straightforward syllogism of transferal, Grotius is able to conclude that 'whatever existed before the establishment of courts, will also exist when the courts have been set aside under any circumstances whatsoever, whether of place or of time. ${ }^{23}$ This claim about transfer is at once conventional and radical; the Scholastic writers on whom Grotius drew for his theory of sovereignty had insisted that sovereign power was the product of consent and the result of a transfer from the people to the sovereign, but there was no corresponding claim that the panoply of sovereign powers originated with individuals. ${ }^{24}$ Thus, as we saw in the case of Suarez, it was entirely consistent to argue that punishment was a power transferred from the people to the sovereign while simultaneously denying that punishment was a possibility for individuals. The novelty of this position is underscored by the weakness of Grotius's evidentiary support; he backs it with the tendentious example of Caesar's attack on a band of pirates who had previously taken him prisoner, which Grotius concludes demonstrates that 'circumstances could exist ... in which it would be possible under the natural law for a private person to inflict punishment upon another person without sinning. ${ }^{25}$

22 IPC, VIII, pp. 136-37.

23 IPC, VIII, p. 140. Structurally, this claim is possible because of Grotius's priority order presentation of the rules and laws of the Prolegomena, with the ultimate conclusion that when two laws cannot simultaneously be satisfied, the earlier laws (which permit punishment) must take precedence of the laws commanding judicial process. IPC, II, p. 49.

24 On the position in Thomist thought that the sovereign held his authority through a contract with the people, see Quentin Skinner, The Foundations of Modern Political Thought, 2 vols. (New York: Cambridge University Press, 1978), II, pp. 148-66. On the variations in this tradition, see Richard Tuck, Philosophy and Government 1572-1651 (New York: Cambridge University Press, 1993), pp. 141-42; Brian Tierney, The Idea of Natural Rights. Studies on Natural Rights, Natural Law, and Church Law, 1150-1625 (Atlanta: Scholar's Press, 1997), pp. 290-315.

25 IPC, VIII, p. 141. Grotius claims that Caesar launched the attack 'when the Proconsul neglected to punish the guilty captives' and killed the captives at sea (IPC, VIII, p. 141). However, this misrepresents his sources; as Paterculus describes it, he handed his captives over into custody, and when Juncus, the judge, decided only to sell the pirates into slavery rather than execute them, 'Caesar returned to the coast with incredible speed and crucified all his prisoners before anyone had had time to receive a dispatch from the consul in regard to the matter.' Velleius Paterculus, Roman History, trans. Frederick W. Shipley (Cambridge: Harvard University Press, 1924), II.42, pp. 141-43. Plutarch at least does not 
These background principles make Grotius's justification of the seizure of the Santa Catarina as an act of private war in Chapter 12 of De Indis a relatively straightforward exercise. ${ }^{26}$ If an individual can engage in warfare, 'no one will maintain that the East India Company is excluded from the exercise of that privilege, since whatever is right for single individuals is likewise right for a number of individuals acting as a group. ${ }^{27}$ With liberal citation of Spanish thinkers, Grotius contended that the right to trade 'cannot be abrogated. ${ }^{28}$ Warfare by the Voc was justified by a laundry list of Portuguese misdeeds, covering each of the four just causes of war identified by Grotius in earlier chapters; initially, the war was just 'to defend the use of those things which, according to natural law, should be commonly enjoyed', 29 such as 'the bare fact that commerce was prohibited. ${ }^{30}$ But more importantly, Grotius argued that the Portuguese were amenable to punishment by the voc as wagers of an unjust war, based on their murder of Dutch sailors at Macao, perfidious conduct, use of poison and assassins, and general violence. ${ }^{31}$

The voc's employment of a private right of punishment was thus made possible by Grotius's conception of an original transfer of the right to punish from individuals to the state, enabling the return of that right in cases of dormancy. This was certainly a bold move in contrast to Scholastic thought, but in most other respects, Grotius's theory of sovereign authority in De Indis reflects a straightforward adaptation of Scholastic principles. This is because the Scholastic tradition of sovereignty provided Grotius two ready advantages.

claim that the judge had reached a decision, but only that he told Caesar 'that he would consider the case of the captives at his leisure,' at which point Caesar 'went to Pergamum, took the robbers out of prison, and crucified them all.' For the full story see Plutarch, 'Caesar' 1.4-2.4; quotation is from 2.3-2.4. Plutarch, Plutarch's Lives, trans. Bernadotte Perrin (London: William Heinemann, 1919).

26 The chapter is most famous in its later revision as Mare liberum, and much of the material in De Indis deals with the question of the ability of the Portuguese to establish sovereignty over the seas or over the lands of the 'infidel' peoples of Asia. In editing the chapter for publication Grotius eliminated the material about the private right of punishment, largely to ensure that the pamphlet did not enflame Spanish opinion during truce negotiations in 1608. Martine Julia van Ittersum, 'Preparing Mare liberum for the Press: Hugo Grotius' Rewriting of Chapter 12 of De iure praedae in November-December 1608', in: Property, Piracy and Punishment, ed. by Blom, pp. 247-75.

IPC, XII, p. 302.

$28 \quad$ IPC, XII, p. 356.

29 IPC, XII, pp. 364-65.

$30 \quad$ IPC, XII, p. 367. See also the justification from self-defense and recovery of possessions (IPC, XII, pp. 370-71).

$31 \quad$ IPC, XII, pp. $373^{-76}$. 
By adapting Scholastic arguments to the case at hand, Grotius could simultaneously vindicate the capture of the Santa Catarina and the warmaking authority of the Dutch state. This tradition also enabled Grotius to explain why the Santa Catarina, which Grotius had not alleged committed any of the Portuguese offenses, was legitimately subject to confiscation. Grotius thus married his vision of transfer with pre-existing Scholastic doctrine - a strategy which carried the added rhetorical benefit of appropriating Spanish sources to the Dutch cause. ${ }^{32}$

In arguing for Dutch legitimacy, Grotius began with the question of who holds the public's right of war. Grotius sees a tight linkage between public and private war, and offers two justifications. While individuals continue to hold a right of war, 'the power to wage war publicly resides primarily in the state.' To demonstrate this, Grotius falls back on the Spanish Scholastics and their definition of the state, in particular the claim that 'a state must be conceived of as something a $\tau \dot{\tau} \alpha x \eta \eta$ s, "self-sufficient," which in itself constitutes a whole entity,' citing Cajetan, Vitoria, and Aristotle. ${ }^{33}$ The right of war is a critical component of self-sufficiency, ensuring the state's ability to protect itself. The sovereign exercises that right by virtue of a transfer from the people; as Grotius puts it,

32 Grotius's reliance on Vitoria and other Spanish sources is manifest throughout his works, even in his unpublished Commentarius in Theses XI. Vitoria is the most cited single writer in Grotius's two primary works, cited 68 times in De Indis and 58 in De iure belli, for a total of 126 cites; the closest second is Vazquez, with 103 (72 in the prior work, 31 in the later), followed by Covaruvvias ( 34 and 52 times, respectively). Antonio Truyol Serra, 'Francisco de Vitoria y Hugo Grocio', Ciencia Tomistica 111 (1984), p. 23. As Richard Tuck has noted, 'the scholastic sources are not particularly prominent in the body of [De Indis]; they appear mainly in a set of footnotes added later.' Tuck Philosophy and Government, p. 171. Of course, this is not true of the straight appropriation of Vitoria's arguments on sovereignty and the authority to punish in the Prolegomena of De Indis, discussed infra, and as we shall see, Vitoria figures prominently in De iure belli as well. Tuck also notes that among the Spanish sources, Vitoria appears to be the one with whom Grotius was most familiar (Tuck, Rights of War and Peace, p. 81). However, more significant is the extent to which Vitoria is cited in Commentarius in Theses XI, Grotius's work on sovereignty and the legitimacy of the Dutch revolt. While scholars have struggled to assign a precise date to the text, the most thorough treatment dates it to the period between 1603 and 1608 , precisely when Grotius would have been working on De Indis. See Peter Borschberg, Hugo Grotius 'Commentarius in Theses XI' (New York: Peter Lang, 1994), pp. 193-99. On Grotius's frequent citation of Vitoria in the work, see ibid, pp. 48-53. The citations were largely used in an effort by Grotius to refute the views of Bodin, and also had the benefit of being less controversial to his intended Spanish audience for the Commentarius. See ibid., pp. 108-09, 115-35.

IPC, VI, p. 96. 
'when the state has once transferred its will into the keeping of the magisterial will, whatever is permissible for the state on its own behalf is likewise permissible for the magistrates on behalf of the state, ${ }^{34}$ including the right of war, which is undoubtedly 'given into the hands of him in whom it has placed the greatest trust'. ${ }^{35}$ The very purpose of the state demands the centralization of the state's warmaking authority in the sovereign.

Grotius applies this theory directly to the Dutch in Chapter 13. Grotius notes that 'the primary and supreme power to make war resides with the state, and ... any perfect community is (so to speak) a true state', and Holland, no less than Castile or Aragon, is its own state, notwithstanding the fact that they share a single king. As a result, 'both by natural and divine law (according to the thoroughly sound conclusion which we borrow from the aforementioned Vitoria), all civil power resides in the state, which is by its very nature competent to govern itself, administer its own affairs and order all its faculties for the common good. ${ }^{36}$ Once again, Grotius stresses that princes exercise that power only as a delegation, a point which Grotius illustrates by reference to the right of war: 'the right to undertake a war pertains to the prince only in the sense that he is acting for the state and has received a mandate from it. ${ }^{37}$ From these premises Grotius concludes that 'it is clear that the state of Holland, even if it was subject to a prince, did not lack authority to undertake a public war independently of that ruler; for otherwise the said state would not have been self-sufficient.' Even if Holland was not analogous to an independent state under an emperor but was instead comparable to a lower magistracy, 'we have maintained, in agreement with Vitoria and with other authorities, that in cases where the prince is inactive, inferior magistrates are empowered not only to repel injuries but also to initiate a public war for the purpose of punishing foreign malefactors,' and that power is even clearer 'when the prince himself does the state an injury that can be checked only by resort to arms. ${ }^{38}$ To drive the point home, Grotius argued that Spanish attacks on the traditional prerogatives of the Low Countries were illegitimate and amounted to an abandonment of any

34 IPC, VI, p. 97.

35 IPC, VI, pp. 97-98.

36 IPC, XIII, pp. 392-93. The citation to Vitoria is 'On civil power' [De potestate ciuili], in: Francisco de Vitoria, Political Writings, ed. by Anthony Pagden and Jeremy Lawrance (Cambridge: Cambridge University Press, 1991), pp. 1-44, § 7 (at p. 12).

38 IPC, XIII, pp. 393-94, citing Vitoria, 'On the law of war' [De iure belli], in Idem, Political Writings, ed. by Anthony Pagden and Jeremy Lawrance, pp. 293-327,§§ 8 and 9. 
sovereign power possessed by Philip, justifying resistance. ${ }^{39}$ This argument grounded Dutch legitimacy firmly in the Spanish tradition of thought; in addition to Vitoria, Grotius cited multiple times to Covarruvias and Vazquez.

Adopting this view also permitted Grotius to define the scope of subject responsibility for sovereign acts, and thus who in the state could be punished for the state's acts, in conventional terms. This resulted in a relatively uncontroversial explanation for why the Santa Catarina was a legitimate target for Dutch acquisition. Broadly speaking, the relationship between the sovereign and the political community was an agency relationship, and the political community could therefore be punished or otherwise held responsible for sovereign acts through war. This responsibility admitted of gradation, and the Scholastic tradition chiefly organized its assessment of responsibility along two axes. One axis addressed the distinction between those who were directly responsible for the war and those who were merely 'innocent' members of the state, while the other axis distinguished between deprivations of property and attacks on the person.

Along each axis, however, the basic fact remained that political communities were responsible for sovereign acts. Vitoria, for example, offered this description of the relationship between subjects and sovereigns:

If a sovereign wages an unjust war against another prince, the injured party may plunder and pursue all the other rights of war against that sovereign's subjects, even if they are innocent of offense. The reason is that once the sovereign has been duly constituted by the commonwealth, if he permits any injustice in the exercise of his office the blame lies with the commonwealth, since the commonwealth is held responsible for entrusting its power only to a man who will justly exercise any authority or executive power he may be given; in other words, it delegates power at its own risk. In the same way, anyone may lawfully be condemned for the wrongdoings of his appointed agent. ${ }^{40}$

39 IPC, XIII, pp. 395-400. Grotius recognized that he was treading well-worn ground by making these arguments, which restated many of the themes already present in Dutch justifications of the rebellion. IPC XIII, p. 395. See Martin van Gelderen, 'Theories of Monarchy and Civil Power in Spanish and Dutch Political Thought, 1555-16og', in: The Origins and Development of the Dutch Revolt, ed. by Graham Darby (New York: Routledge, 2001), pp. $151^{-} 70$.

$40 \quad$ Vitoria, 'On civil power', § 12, p. 21. 
As Vitoria's reference to subjects 'innocent of offense' suggests, this agency relationship did not lead to unlimited punishment of an enemy nation. The organizing principle was the claim that, with respect to life, only those enemy subjects who were 'responsible' for the war in some sense were subject to threats to their lives as a result of their behavior. Disputes within the Scholastic approach accepted this basic principle, but contested its scope. Vitoria, for example, took the position that even after victory is secured it is lawful under certain circumstances to kill all the enemy soldiers, since they are 'responsible for the injury inflicted.. ${ }^{41}$ The same rationale justifies killing all those among the enemy who surrender, and it is only an agreement among Christian nations that protects prisoners from being justly killed as well. ${ }^{42}$ Molina adopted an effectively identical position. ${ }^{43}$ While Suarez agreed with the general premise, he took issue with Vitoria's claim that 'all the adult men in an enemy city are to be thought of as enemies, since the innocent cannot be distinguished from the guilty; and therefore they may all be killed.' ${ }^{44}$ While 'human judgment looks upon those able to take up arms as having actually done so,' implying such individuals are subject to punishment, Suarez advocates for a presumption of innocence in the absence of clear evidence of culpability. ${ }^{45}$

Those who shared in some guilt for the war were contrasted with the 'innocents' in a political community, who were categorically excluded from punishment or even deliberate targeting. Broadly speaking, two rationales explained these restrictions. One rationale excluded those who are in some sense unconnected to the state; thus Suarez shielded foreigners and travelers, who 'are no part of the state, ${ }^{46}$ and Molina sheltered clerics, since 'they are not considered

41 Vitoria, 'On the law of war', $\S \S 46,48$, pp. 320-21.

42 Ibid., § 49, pp. 321-22.

43 Luis de Molina, De iure et iustitia in sex tomis divisa, Vol. 1 (Mainz: Joannis Godefridi Schönwetteri, 1659; 1st edn 1593), Disp. 122, pp. 470-71. See also Lucas Garcia Prieto, La paz y la guerra. Luis de Molina y la escuela española del siglo XVI en relación con la ciencia y el derecho internacional moderno (Zaragoza: Octavio y Felez, 1944), pp. 246-49, who notes the similarities between Vitoria and Molina on this issue.

44 Vitoria, 'On the law of war', § 38, pp. 316-17.

45 Suarez, 'On Charity', in: Selections from Three Works of Francisco Suarez, pp. 799-868, $\S 7$, at pp. 843, 846-47. I include Suarez here because while his comments on war (like his famous work on law) were not available to Grotius when he wrote De Indis (not being published until 1621 and 1613 , respectively), they were in print by the time of the first edition of De iure belli. However, as will be clear, Suarez said little that would have surprised Vitoria or Molina on these questions.

Ibid. p. 843 . 
parts of the Republic'.47 The second rationale was the claim that certain individuals, even if nominally members of the state, could not be guilty of an offense, because they could not participate in war or lack the rationality to commit crimes. On this account, Suarez declared that ' $[\mathrm{i}] \mathrm{t}$ is implicit in natural law that the innocent include children, women, and all unable to bear arms.'48 Molina took a somewhat broader view, contending that women who accompany enemy forces or assist in sieges are amenable to punishment. ${ }^{49}$ Vitoria likewise argued that women, children, the elderly, and clerics are protected, though he was not entirely clear about whether this had its origin in natural law or custom. ${ }^{50}$

Mere membership in the state was thus insufficient to place an otherwise innocent citizen at risk of legitimate targeting during war. That exemption, however, did not carry over to the property of such citizens, and the Scholastic tradition drew important distinctions along this second axis. The overwhelming consensus was that all members of the state-even 'innocents' - might be subject to confiscation of property in order to satisfy a penalty imposed by a just victor. As Suarez described it, taking a line quite similar to Molina, ${ }^{51}$ while the victor's first step should be to seek restitution from the guilty, 'the innocent form a portion of one whole and unjust state; and on account of the crime of the whole, this part may be punished even though it does not of itself share in the fault. 52 The victor's greater right over property is attributable to the fact that the state 'has a higher right' to property than to life, which 'does not fall under human dominion. ${ }^{53}$ Both Molina and Vitoria also made the connection between this principle and the practice of reprisal; after all, as Vitoria put it, leaders who fail to give appropriate reparation for an unjust taking of property 'put themselves in the wrong ... and the injured prince can therefore seek satisfaction from any or all members of the offending commonwealth. ${ }^{54}$

47 Molina, De iure et iustitia, Disp. 119, no. 5, p. 465. Suarez, by contrast, referred this effect to the canon law. Suarez, 'On Charity', § 7, p. 843 .

48 Ibid.

49 Molina, De iure et iustitia, Disp. 119, no. 3, pp. 464-65. On Molina's attitude toward innocents in general, see Joao Manuel A.A. Fernandes, 'Luis de Molina: On War', in: A Companion to Luis de Molina, ed. by Matthias Kaufmann and Alexander Aichele (Leiden/Boston: Brill, 2014), pp. 236-39; Garcia Prieto, La pazy la guerra, pp. 230-46.

$5^{0} \quad$ Vitoria, 'On the law of war', § $35^{-36}$, pp. 314-15.

$5^{1} \quad$ Molina, De iure et iustitia, Disp. 121, pp. 467-69.

52 Suarez, 'On Charity', § 7, p. 843.

53 Ibid. p. 845 .

54 Vitoria, 'On the law of war', § 41, p. 318; for Molina, see Molina, De iure et iustitia, Disp. 121, pp. 467-69. 
While Grotius was to turn sharply against this traditional framework in $D e$ iure belli ac pacis, in De Indis he adopted it wholeheartedly because it served his purposes by legitimizing the capture of the Santa Catarina. At the outset, Grotius adopts the description of an agency relationship between subjects and sovereigns, citing Vitoria's discussion of the same question:

As for the state, it is bound by the act of its magistrate as if by the force of a contract, just as he who has set up a director or agent in some matter is bound; and at times this binding obligation embraces even liability to punishment. For those persons are liable, who have transferred authority over themselves to such representatives as might prove to be the source of injury to others, since he who has put his trust in an unworthy individual would seem to be involved, so to speak, in the fraudulence of the latter. ${ }^{55}$

Grotius likewise retains the distinction between innocent members of the state and those directly responsible for the war, employing readily recognizable terminology. Every subject of an enemy sovereign is classified as an enemy because he participates in resisting the restoration of our right, even if he does not directly consent to doing so: 'he who resists a just execution, whether knowingly or ignorantly, causes an injury, since he either keeps back what belongs to another or fails to do that which he is under an obligation to do, and since, moreover, he is also offending against one whom he ought not to offend. ${ }^{56}$ All enemies who actively resist restoration of our right may be attacked, but 'if there are some individuals who can be separated from the whole body of the enemy and who do not impede the execution of our rights, such individuals should of course be spared altogether from attack upon their persons. ${ }^{57}$

The like is true of Grotius's approach to questions of property. The taking of property, even from the innocent, is legitimate because all collective bodies, public and private, 'are subject to the rule that whatever is owed by the companies themselves may be exacted from their individual partners,' and 'it is obvious that the state is constituted by individuals just as truly as the magistrate is constituted by the state, and that therefore the said individuals are liable in the same fashion in so far as concerns reparation for losses, even when the claim

55 IPC, VIII, pp. 155-56. Grotius cites Vitoria's 'On civil power', § 12, quoted in relevant part above.

56 IPC, VII, p. 113 .

57 IPC, VIII, p. 161. 
in question is founded on wrongdoing. ${ }^{58}$ Grotius likewise employs this notion to justify the practice of reprisal, calling it the 'sole argument' for its legitimacy: 'For what is owed to me by the citizen of a state is owed by the state, too, when the latter does not enforce the claims of justice; and what is owed by the state, is owed by its individual citizens. 59

When Grotius turned to laying out the specific justification for the capture of the Santa Catarina as a matter of private war, he melded these traditional principles with his more radical assertions about the private right of punishment. The Santa Catarina was a legitimate target because 'a state and its magistrates incur guilt when they fail to curb the openly shameful conduct of their own people,' and as a result the whole Portuguese 'nation connived at the evil deeds' Grotius described. ${ }^{60}$ Since 'acts which have taken place because of the state's decision, and even those which have been decreed by a major part of the whole state or by the magistrates, are acts of the whole community, ${ }^{\prime 61}$ the voc could legitimately seek to punish the Portuguese on account of the long list of offenses they had committed against the Dutch and then failed to properly punish. After all, 'there is nothing to prevent a war from being private on one side, public for the other, and at the same time just for the former. ${ }^{\prime} 2$

\footnotetext{
$58 \quad$ IPC, VIII, pp. $15^{8-59 .}$

59 IPC, VIII, pp. 159-60.

6o IPC, XII, p. 376 .

$61 \quad$ IPC, XII, p. 377.

62 IPC, XII, p. 377. Grotius does strain against this rationale at points. In applying his theoretical findings to the case of the Portuguese, Grotius offers an additional justification: every Portuguese subject is liable to attack 'partly because subjects are compelled to defend their state.' (IPC, XII, p. 379). But the claim that subjects are obligated to defend their state cannot itself explain why all subjects are amenable to attack; Grotius had argued that subjects in fact do not always have an obligation to participate in a state's war when it is palpably unjust. Subjects are obligated to fight for the state, Grotius had concluded, in doubtful cases, or those in which the war was just, and he conceded elsewhere that he would 'not categorically deny the possibility of good faith on the part of the Portuguese.' (IPC, XII, p. 418). Yet even under these circumstances, Grotius's conclusion does not follow, since he had also made a distinction between enemies who actively resist our right and those who do not. Grotius attempts to support this claim with a lengthy quotation from Augustine about the relationship between individuals and the state, concluding that 'extreme and headstrong obstinacy of the Portuguese, with which they strive-both as a body and individually, uniting their fortunes and their corporeal strength for the attainment of their purpose - to prevent any Dutchman from being safe in India' properly subjects all Portuguese to 'warlike attack,' but Grotius has gone beyond his theory in this claim about subject liability. (IPC, XII, p. 379). Grotius cites Augustine's On the Heptateuch, qu. 26, On Leviticus.
} 
Grotius thus borrowed from traditional Scholastic notions of sovereignty to make the case that the acquisition of the Santa Catarina was legitimate as an exercise of private warmaking authority. From a theoretical standpoint, the greatest challenge was establishing the private right to engage in punishment; as Grotius described it in understated terms, '[t]he difficult part of our problem lies in the fact that the power to begin a war would not seem to be granted readily to private parties. ${ }^{\prime 63}$ If that principle were accepted, however, much of the rest of Grotius's argument justifying the capture represented a relatively conventional application of Scholastic principles, ${ }^{64}$ in particular the claim that subjects were amenable to punishment for the acts of their state. However, Grotius was to abandon many of the Scholastic underpinnings of this aspect of his thought in De iure belli ac pacis.

\section{De iure belli ac pacis and the Restructuring of Sovereignty}

Grotius's De iure belli ac pacis is a much more ambitious work than his youthful De Indis. This is in part due to Grotius's stated purpose, which was to show both that war was a legitimate activity for Christians (against Erasmus and other Protestant pacifists) and the proper limits on its conduct.65 Those limits were presented in Book III, and take the form of both a set of capacious permissions for just and unjust belligerents and an extensive list of moral restraints on the conduct of warfare which belligerents ought to observe. The content of these laws of war gave rise to a spirited debate about their 'modernity', as scholars have attempted to trace the relationship between the modern laws of war and Grotius's specific pleas for 'moderation' in Book III. ${ }^{66}$

Grotius's treatment of sovereignty has long been recognized as one of the substantially new features of De iure belli ac pacis, and attention has often focused on its absolutist features. Grotius acknowledged that societies could

63 IPC, XII, p. 379.

64 Of course, Grotius's argument that the seas of the East Indies must be open to Dutch commerce was central to the justness of the Dutch cause regardless of its public or private nature-hence the publication of that argument separately, stripped of the controversial claims about private punishment.

65 Prolegomena, $\S 29$, p. 20 . All citations to De iure belli ac pacis [IBP] are to On the Law of War and Peace, trans. Mark Kelsey (Oxford: Clarendon Press, 1925).

66 For summaries of this trend, see Tanaka Tadashi, 'Temperamenta', in: A Normative Approach to War, ed. by Onuma, pp. 304-07; G.I.A.D. Draper, 'Grotius's Place in the Development of Legal Ideas About War', in: Hugo Grotius and International Relations, ed. by Hedley Bull et al. (Oxford: Clarendon Press, 1990), pp. 176-207. 
wholly alienate rights as part of the original contract, creating a sort of civil slavery, and even contended that this would be entirely desirable under certain circumstances. ${ }^{67} \mathrm{He}$ likewise took a very strong stance against resistance to sovereign acts, concluding that the state, by virtue of its higher right over individuals, could (and in every state, actually did) limit the right of resistance against the sovereign. ${ }^{68}$ Grotius's theory, however, also had a more libertarian side rooted in a notion of interpretive charity. Because the arrangement of sovereign power was dictated by the content of the agreement that instituted that power, in cases of doubt, Grotius argued that the most logical assumption was that individuals would not contract into particularly disadvantageous relationships. ${ }^{69}$

Yet conspicuously absent from De iure belli ac pacis is anything like the transfer theory which had been Grotius's primary innovation in De Indis. In fact, Grotius is never clear about the precise origin of sovereign powerswhether the result of transfer, a notion of Aristotelian self-sufficiency, or a renunciation of individual rights in favor of the private right of the sovereign. Diverse efforts have been made to fill this gap. It has variously been seen as an attempt to step back from the strongly individualist transfer theory of $D e$ Indis, 'balancing' it with aspects of Scholastic thought; ${ }^{70}$ a claim that the only thing which is surrendered in the initial contract is 'the right to punish others' as a more general form of the right to resist the sovereign $;{ }^{71}$ and, in the most thorough treatment, as evidence that the ruler's right to punish has the same derivation as in Hobbes's Leviathan: 'the subjects did not give the sovereign that right to punish; but only in laying down theirs, strengthened him to use his own, as he should think fit, for the preservation of them all. ${ }^{72}$

All of these explanations pick up on important elements of Grotius's thought, but none fully engages with the contexts in which Grotius permits the continued use of the right of punishment by individuals or the sharp reversal of his views on collective punishment. Critically, Grotius does not replace the transfer theory with anything like the Scholastic notion of the powers

67 IBP, I.3.8, pp. 103-04. On this point, see Tuck, Natural Rights Theories, p. 77; Knud Haakonssen, 'Hugo Grotius and the History of Political Thought', Political Theory 13 (1985), pp. 244-45.

68 IBP, I.4.2, p. 139.

69 This point is made forcefully in Tuck, Natural Rights Theories, pp. 79-8o. For textual examples of this style of argument, see IBP, I.4.7., p. 149; IBP II.5.24, pp. 253-54.

70 Tierney, Natural Rights, pp. 333-39.

71 Haakonssen, 'Hugo Grotius and the History of Political Thought', pp. 245-47. Haakonssen cites IBP, I.4.2 for this proposition (p. 139 of the Kelsey translation).

72 Van Nifterik, 'Grotius and the Origin of the Ruler's Right to Punish', pp. 411-12. 
necessary for a self-sufficient state which he had appropriated in De Indis or a Bodinian account of the powers inherent in true sovereignty. Grotius's new approach to sovereignty speaks in terms of a 'surrender' of individual rights to the collective, emphasizing that the degree to which any particular individual right has been surrendered is a product of the original agreement constituting the state. Yet although he sometimes alludes to certain rights which must necessarily have been given up in the course of creating civil power, he is vague about what those rights are. Nowhere is this vagueness clearer than in Grotius's discussion of punishment. As we will see, Grotius without explanation split the treatment of punishment for the good of the victim and punishment for the good of mankind, arguing that the former could return to individuals in times of dormancy while suggesting that the latter could not.

Yet this vagueness also had its virtues. Most importantly, in detaching himself from the Scholastic tradition, Grotius discarded the agency relationship between subjects and sovereigns that had been central to his claims in De Indis. Paired with the fact that, unlike Hobbes, he offered no theory of subject authorization of sovereign acts, this shift enabled Grotius to make claims about moderation in warfare that shielded virtually all members of society from targeting, punishment, or confiscation of property as a matter of natural law. In addition, Grotius's emphasis on the initial contract as determining the scope and distribution of sovereign power not only enabled him to justify the Dutch revolt in familiar terms, but also to insist that natural law imposed no constraints preventing private actors from engaging in war, either on their own account or on behalf of the public.

Grotius's ambiguity about the origins of sovereign authority is apparent almost immediately in De iure belli ac pacis. As in De Indis, he tightly links the issues of legitimate warmaking authority and sovereign power. Because 'a public war ought not to be waged except by the authority of him who holds the sovereign power', in order to properly understand the laws of war 'it will be necessary to understand what sovereignty is, and who hold it. ${ }^{73}$ Yet understanding what sovereignty is does not involve the same tasks as understanding the origin of the particular powers the sovereign wields, and Grotius's discussion of sovereignty largely ignores this question.

The reader is thus left to glean insights from Grotius's scattered comments addressing specific issues. Instead of the hybrid transfer and self-sufficiency theory present in De Indis, Grotius shifts to an account that emphasizes limitations on the subject's rights in light of the 'subjection' created by civil society. 
The first hints of this theory appear in the Prolegomena, where Grotius's initial description of the foundation of society describes municipal law as rooted in the obligation to abide by pacts. ${ }^{74}$ Thus, he contends, 'those who had associated themselves with some group, or had subjected themselves to a man or men, had either expressly promised, or from the nature of the transaction must be understood impliedly to have promised, that they would conform to that which should have been determined, in the one case by the majority, in the other by those upon whom authority had been conferred. ${ }^{75}$ Municipal law thus rests on 'mutual consent' driven by the benefits of 'subjection to authority' for creating an advantageous social existence. ${ }^{76}$

The precise content of this initial consent to subjection is not clear, and appears highly context-dependent. For example, Grotius opened his chapter on rebellion by noting that while individuals originally hold a right to resist injury, at the creation of civil society 'the state forthwith acquires over us and our possessions a greater right' in order to ensure domestic peace. ${ }^{77}$ This 'greater right' was justified by the needs of society; without the power to limit resistance, it could not 'achieve its end' of securing peaceful coexistence. ${ }^{78}$ Even the scope of this surrender, however, is subject to bargaining:

Now this law which we are discussing - the law of non-resistanceseems to draw its validity from the will of those who associate themselves together in the first place to form a civil society; from the same source, furthermore, derives the right which passes into the hands of those who govern. If these men could be asked whether they purposed to impose upon all persons the obligation to prefer death rather than under any circumstances to take up arms in order to ward off the violence of those having superior authority, I do not know whether they would answer in the affirmative, unless, perhaps, with this qualification, in case resistance could not be made without a very great disturbance in the state, and without the destruction of a great many innocent people. ${ }^{79}$

\footnotetext{
74 IBP, Prolegomena, § 15, p. 14.

75 Ibid. p. 15 .

76 Prolegomena, $\S 16$, p. 15 .

$77 \quad$ IBP, I.4.2, p. 139 .

78 Ibid.

79 IBP, I.4.7, p. 149. On this passage, see Tuck, Philosophy and Government, p. 20o; Tuck, Natural Rights Theories, pp. 79-8o; van Nifterik, 'Grotius and the Origin of the Ruler's Right to Punish', p. 412 \& n. 51.
} 
Although this passage makes clear that the scope of the right to resist must be determined by reference to the initial contract constituting the civil society, it does not describe a transfer of a power from the individual citizen to the state, nor does it provide any other easily identifiable description of the origin of sovereign powers. Indeed, this claim is not far from one advanced in writers like Suarez, in which the consent of individuals is necessary to create civil society in the first instance. To the extent that just resistance is the exercise of a particular form of the right of war-self-defense-many writers in the Scholastic tradition had recognized that individual resistance would be permissible against tyrants on the basis of the tyrant's lack of a contract (in the case of an illegitimate usurper) or violation of the compact between sovereign and people. ${ }^{80}$ The novel feature of Grotius's argument was the claim that individuals could have completely renounced this right, but interpreted fairly had almost certainly chosen not to. Of course, this account also preserved Grotius's ability to appeal to the specifics of Dutch political arrangements to justify the ongoing revolt. In De iure belli ac pacis, Grotius specified that resistance was legitimate if by particular contractual arrangements the right to resistance was reserved or if 'the sovereign power is held in part by the king, in part by the people or senate' and the king 'attempts to usurp that part of the sovereign power which does not belong to him' ${ }^{81}$

Yet this focus on the contractual arrangement governing any particular society puts Grotius in an odd position throughout De iure belli ac pacis when describing rights of sovereignty. As van Nifterik has observed, 'the real question is: the use of which natural liberties have the founders of a civil society been willing to renounce in order that they may exclusively be used by the civil authorities for the sake of all?'82 By conceding that any individual rights could be renounced, Grotius opened himself to the recurring question of what individual rights had been (or must have been) renounced to form civil society, and under what terms. Although Grotius occasionally implied that some limited set of rights must be renounced in order to create civil society, he was never clear about what those rights were, and he never attempted to justify any particular set of arrangements or renunciations as necessary prerequisites to

8o Suarez, 'On Law and God the Lawgiver', III.2.1-5, pp. 372-77; 'Defense of the Catholic and Apostolic Faith', in: Selections from Three Works of Francisco Suarez, pp. 647-727, vi.2.1, 6, at pp. 705, 709-10. On this point, see Tierney, Natural Rights, pp. 309-15, 337-38.

81 IBP, I.4.13-14, pp. 158-59.

82 Van Nifterik, 'Grotius and the Origin of the Ruler's Right to Punish', p. 412. Van Nifterik points out that Grotius is not entirely consistent about his position on the right of punishment between De iure belli and his De satisfactione. 
the creation of sovereign power. In the Prolegomena, for example, he identifies the individual's consent to abide by the determinations of those with sovereign power as central to the creation of civil society, but he elsewhere implies that such subjection has its limits. For example, subjection does not remove a subject's ability to refuse military service in an unjust war, and Grotius suggests that subjects may refuse even if the justice of a war is merely doubtful. ${ }^{83}$ Similarly, he states that the civil power encompasses '[e]xclusively public interests' like 'the making of peace, of war, and treaties', ${ }^{84}$ but as we will see, that does not amount to a claim that the power to make war is exclusive to the state.

The persistent ambiguity of Grotius's arguments on this point is underscored by his greatly expanded discussion of punishment in De iure belli ac pacis. While spelling out the arguments for just causes of war, Grotius notes that 'in a private war, self-defense is generally the only consideration; but public powers have not only the right of self-defense but also the right to exact punishment. ${ }^{85}$ Grotius does not go into detail here, but this marks a shift from his earlier account, in which punishment was an acceptable justification for private war even after the institution of civil society. When Grotius finally reaches his detailed discussion of punishment in Chapter 20 of De iure belli ac pacis, he begins by defining it as 'an evil of suffering which is inflicted because of an evil of action', ${ }^{86}$ and he analogizes to a contract of sale with implied conditions: 'so he who does wrong seems by his own will to have obligated himself to a penalty, because a serious crime cannot be unpunishable; hence, whoever directly wills to sin, by consequence has willed also to deserve a penalty.' ${ }^{87} \mathrm{This}$ obligatory aspect of punishment is important because it enables Grotius to retain the critical argument from De Indis that 'the subject of this right, that is that agent to whom the right is given, has not been definitely fixed by nature itself:'88 This denies any claim that by nature the state has exclusive claim to the right of punishment, since even though 'nature makes it clear enough that it is most suitable that punishment should be inflicted by a superior,' the term

83 IBP, II.26.3, p. 587 ('If those under the rule of another are ordered to take the field, as often occurs, they should altogether refrain from doing so if it is clear to them that the cause of the war is unjust.'); IBP, II.26.4, p. 593 (A subject should refuse to participate in a war if he 'not only hesitates, but, led by more convincing arguments, leans rather to the view that the war is unjust.').

84 IBP, I.3.6, p. 102.

85 IBP, II.1.16, p. 184.

86 IBP, II.20.1, p. 462.

87 Ibid. pp. $464-65$. On the view that a wrongdoer wills his own punishment, see Andrew Blom, 'Owing Punishment: Grotius on Right and Merit', Grotiana 36 (2015), 3-27.

88 IBP, II.20.3, P. 465 . 
superiority must be 'understood to imply that he who has done wrong by that very act may be considered to have made himself inferior to some one else and as it were to have demoted himself from the class of men into the class of beasts which are subject to man. ${ }^{89}$ This leaves open the possibility of individual punishment for three potential purposes: the 'advantage of the person who does wrong, or of the person against whose interest the wrong was committed, or of other persons in general, ${ }^{90}$ each of which Grotius addresses in turn.

Just as in De Indis, Grotius continues to argue for the persistence of an individual right to punish, at least for the benefit of 'the person against whose interest the wrong was committed.' On this head, 'vengeance, even if it is exacted by private individuals, is not unlawful according to the bare law of nature, that is apart from divine and human laws and from chance circumstances. ${ }^{91}$ This right has largely been preempted by the state, although Grotius is no clearer here about precisely how that comes about. His account merely notes that state control over punishment is encouraged by the partiality we feel towards ourselves and our family, such that 'as soon as numerous families were united at a common point judges were appointed, and to them alone was given the power to avenge the injured, while others are deprived of the freedom of action wherewith nature endowed them. ${ }^{\prime 2}$ But at the very least, it is clear that this preemption is only internal and contingent; the old argument from 'dormancy' makes an appearance here alongside a familiar example:

Nevertheless, the old natural liberty remains, especially in places where there are no courts, as, for example, on the sea. An example of this is perhaps the conduct of Julius Caesar. He, while yet a private citizen, with a hastily levied fleet pursued the pirates by whom he had been captured, sank some of their ships, and put the rest to flight. When the proconsul failed to punish the pirates who had been taken, he himself set out to sea and crucified them. The same right will exist in desert places, or where men lead a nomadic life. ${ }^{93}$

In De Indis, Caesar served as evidence for the claim that individuals not only hold a right of punishment, but can exercise it over any offenses in the absence

\footnotetext{
89 Ibid.

$90 \quad$ IBP, II.20.6, p. 470.

91 IBP, II.20.8, p. 472.

92 IBP, II.20.8, p. 473.

93 IBP, II.20.8, p. 475 .
} 
of state action or authority. Here, Grotius ties it to the specific case of punishment on behalf of the individual who was injured.

Punishment for 'the good of mankind in general, ${ }^{94}$ by contrast, has apparently been entirely lodged in the state. This is despite the fact that individuals have no less claim to it: 'the possession of the right to punish for this purpose also, according to nature, may rest with any person whatsoever. ${ }^{95}$ When Grotius turns specifically to the case of a punitive war waged against violators of natural law, he suggests that this right is exclusive to the state:

The fact must also be recognized that kings, and those who possess rights equal to those kings, have the right of demanding punishments not only on account of injuries committed against themselves or their subjects, but also on account of injuries which do not directly affect them but excessively violate the law of nature or of nations in regard to any persons whatsoever. For liberty to serve the interests of human society through punishments, which originally, as we have said, rested with individuals, now after the organization of states and courts of law is in the hands of the highest authorities, not, properly speaking, in so far as they rule over others but in so far as they are themselves subject to no one. For subjection has taken this right away from others. ${ }^{96}$

There is no discussion-as we might expect from Grotius's theory of resistance - of why individuals should be fairly assumed to have given up the right to punish for the good of mankind, or an implication that they could have retained this power if they had chosen. ${ }^{97}$ In the original discussion, the closest thing Grotius gives to an explanation is the suggestion that because determination of a proper punishment 'requires much prudence and fairness ... men have agreed to select as arbiters those who they think are best and

94 IBP, II.20.9, p. 475 .

95 IBP, II.20.9, p. 476.

96 IBP, II.20.40, pp. 504-05.

97 This passage also approaches the closest to a Hobbesian position. This is essentially the argument advanced by van Nifterik, who contends that '[s]ubjection entails the loss of the natural right to punish and to defend what is ours, and the highest authorities rule over men exactly because they are subject to no one and thus can still use their natural powers according to natural law.' Van Nifterik, 'Grotius and the Origin of the Ruler's Right to Punish', p. 410. Although that explanation neatly captures some features of Grotius's position, particularly in the domestic realm, it does not explain Grotius's apparently disparate treatment of the right to punish on behalf of the victim and on behalf of mankind as a whole in the international arena. 
wisest. ${ }^{98}$ But this is equally true of punishment for the good of the victim; why has 'subjection' not categorically removed the right of subjects to engage in punishment for that purpose? This is especially curious given that Grotius had implied that there are circumstances when individuals who have entered civil society regain the right to punish for the benefit of all mankind: 'as ... in the case of vengeance ... traces and survivals of primitive right persist in those places and among those persons who are subject to no fixed tribunals, and in some other exceptional cases.' The two passages are reconcilable if Grotius is here more narrowly referring to peoples who live without settled government (and thus no system of 'subjection' removes their original right), ${ }^{99}$ but this explanation does not explain why he draws a parallel with 'the case of vengeance.'

Abandoning the Scholastic features of the account of sovereignty Grotius had employed in De Indis did, however, create one substantial advantage. It enabled Grotius to break away from the Scholastic tradition's views on collective responsibility in the international realm, which in turn furthered Grotius's pleas for moderation in warfare. If sovereign authority was nothing more than an agreement about subjection, with no corresponding agency relationship, it became more difficult to argue that individuals were personally liable for the acts of the state. Put another way, Grotius lacked any account of authorization which connected subjects to their sovereign's deeds. ${ }^{100}$ The practical upshot of this view was that Grotius rejected the assertion that by virtue of natural law membership in a political community could subject a person to punishment for the unjust acts of a sovereign, paving the way for Grotius's expansion of the protections extended to enemies in his calls for moderation.

Grotius's argument against collective punishment rests on a relatively simple claim: 'an obligation to punishment arises from desert; and desert is

$98 \quad$ IBP, II.20.9, p. 477.

99 IBP, II.20.9, p. 477. Grotius had examples of these sorts of communities; in discussing the right of punishing for the good of the victim, for example, Grotius noted cases 'where men lead a nomadic life' as instances where the private right of punishment prevails, IBP, II.xx.8, p. 474, and later suggested that 'even now' the law of nature about punishment is 'enforced, in places where men live in family groups and not states,' IBP, II.XX.40, p. 506. For 'exceptional cases,' Grotius referred to a Jewish law permitting anyone to kill a fellow Jew 'who fell away from God and the law of God,' and the 'full right of punishment' permitted to parents and masters in places like Sparta. IBP, II.20.9, pp. 477-78.

100 Compare Hobbes's famous theory of authorization, by which every man is said to 'Authorise all the Actions and Judgements, of that Man, or Assembly of men, in the same manner, as if they were his own.' Leviathan, ed. Richard Tuck (New York: Cambridge University Press, 1996), p. 121. 
something personal, since it has its origin in the will, than which nothing is more peculiarly ours; hence the expression "in one's own power". From this principle, Grotius concludes that subjects can never lose their private property because of a wrong done by the community without their consent'. ${ }^{101}$ The principles applicable to subjects parallel those applicable to children, who likewise cannot share in the personal guilt attributable to their parents. ${ }^{102}$ In addition, even when the community is liable to punishment for some act, the duration of that desert depends on the continuing presence of some individuals who are guilty of the act in question. ${ }^{103}$

However, as Grotius's reference to wrongs done 'without their consent' indicates, it is possible for individuals to be liable to punishment for state acts under certain circumstances. Notably, this liability is no longer the consequence of an agency relationship between subjects and sovereigns. Instead, Grotius argues that 'guilt will pass from the highest authority to those subject to it, if those subject to it have consented to crime, or if they have done anything by order or advice of the highest authority which they could avoid without committing wrong.' ${ }^{104}$ Even in a community where citizens participate directly in government, Grotius limits the scope of punishment of a community by stressing that 'Guilt ... attaches to the individuals who have agreed to the crime, not to those who have been overmastered by the votes of others. For the punishments of individuals and a community are different.' ${ }^{105}$ In the most extreme case, communities are punished by their dissolution and destruction-the equivalent of the death penalty for individuals - or by confiscation of collective goods, such as public lands, money, and military supplies. ${ }^{106}$ That punishment, however, does not properly extend to the individual citizens, at least insofar as they did not consent to the misdeeds.

As this discussion implies, relatively fine-grained distinctions must be made among different subjects and arrangements of sovereign authority in apportioning responsibility:

\footnotetext{
$101 \quad$ IBP, II.21.12, p. 539.

102 IBP, II.21.13, P. 540.

103 IBP, II.21.8, p. 536.

104 IBP, II.21.7, p. 534. Grotius illustrates this by way of citation to the same passage of Augustine which he had employed in De Indis, emphasizing that the community cannot exist in the absence of individuals. Ibid. pp. 534-35.

105 Ibid. p. 535 .

106 Ibid.
} 
What we have said with regard to the inflicting of evil upon children because of the wrong-doings of their parents may be applied also in the case of a people that is truly subject (for a people that is not subject may be punished because of its own guilt, that is for its negligence, as we have said), if the question is raised whether such a people may suffer for the crimes of its king or its rulers. At present we are not inquiring whether the consent of the people itself is involved, or whether there has been any other act on the part of the people deserving of punishment; we are concerned merely with the relation which arises from the nature of the body whose head is the king, and whose members are the other citizens. ${ }^{107}$

Certain arrangements of sovereign power-particularly those in which the sovereign wields absolute authority —are particularly unlikely to subject individual members of the society to liability. This is not to say that individuals cannot be responsible for state acts in absolute monarchies; Grotius provides Biblical examples of instances when even a 'people that is truly subject' has consented in such a fashion as to create liability to punishment. ${ }^{108}$ But the critical point-and the crucial break from the tradition Grotius endorsed in De Indis-is that there is nothing in the subject-sovereign relationship per se which imposes that liability on subjects. The agency relationship between ruler and ruled no longer supplies the necessary link.

Abandoning traditional notions of collective responsibility suggested limits on legitimate punishment in the international order which are quite extreme: no subject could ever be punished with confiscation of property, and certainly not with death, on account of his sovereign's acts. Yet taking this radical

107 IBP, II.21.17, pp. 543-44.

108 Grotius first quotes Philo's commentary on Genesis 12, in which 'the Lord plagued Pharaoh and his house with great plagues because of Sarai Abram's wife,' and endorses Philo's claim that the household was punished because 'none of them had felt any indignation at his lawless conduct, but had all consented to it, and had all but co-operated actively in his iniquity.' Philo, 'On Abraham' 19, in The Works of PhiloJudaeus, Vol. II, trans. C.D. Yonge (New York: George Bell \& Sons, 1894), p. 415. He also cites Josephus's interpretation of the story of Jeroboam in 1 Kings 14 , who is told that God 'will give Israel up because of the sins Jeroboam has committed and has caused Israel to commit' in worshipping the goddess Asherah. 1 Kings 14:16 (NIV). Josephus's description of this event stresses collective responsibility: 'The multitude also shall themselves partake of the same punishment ... because they have followed the wicked practices of their king, and have worshipped the gods that he made, and forsaken my sacrifices.' The Works of Flavius Josephus, trans. William Whiston (Buffalo: John E. Beardsley, 1895), viii.11.1. Grotius cites the same passage of 1 Kings elsewhere in a similar connection. See IBP, I.3.8, p. 111. 
position effectively ruled out war as commonly practiced. Grotius's response to this reality was multifold. To begin, Grotius was keen to explain that legitimate punishment of the state qua state could exist without also being a punishment of the citizens who make it up, because the proper exercise of a right which results in some loss to a third party is not an injury to that person. Grotius makes this point in two ways. First, some harms result only as a consequence of the legitimate punishment of another: confiscation of the property of parents, though it creates 'inconvenience' for their children, 'is not a punishment, because the property that was to be theirs would not become theirs actually unless it had been preserved by their parents to the end of life. ${ }^{\prime 109}$ On this account, Grotius contends that the direct punishment of the state (through, say, the loss of 'political liberty' or 'fortifications') is felt by innocent citizens 'only in respect to such things as belonged to them not directly but through the community'. ${ }^{110}$ Second, Grotius analogizes citizens to sureties. A surety suffers a loss 'not in such a way that fault is the proximate cause of the act,' but 'the immediate cause of the obligation is the promise itself'.111 Under such circumstances, the loss is not a punishment, properly speaking. A similar situation occurs when an individual loses a right which is 'terminable at the pleasure of the grantor' or when a subject loses property as the result of the exercise of the right of eminent domain; 'there is in this not properly a punishment, but the execution of an antecedent right that was vested in the person who takes the thing away.'112

This careful parsing of what is properly termed 'punishment' reflects Grotius's more sophisticated approach to the distinction between punishment and reparation in De iure belli ac pacis. As Benjamin Straumann has pointed out, in De Indis Grotius used delictum to refer both to torts giving rise to demands for restitution and to criminal acts, but by the time of De iure belli ac pacis Grotius distinguished clearly between the two situations, and provided different treatment for takings based on reparation and punishment. ${ }^{113}$ In each case, however, Grotius argued that the key determinant of subject exposure was not the law of nature, but the law of nations.

Grotius's treatment of reprisals, for example, refers their justification entirely to the law of nations. The description of citizens as sureties played a key role in this argument. Grotius begins his discussion of reprisal by reiterating

\footnotetext{
109 IBP, II.21.10, p. 537.

110 IBP, II.21.10, p. 538.

111 IBP, II.21.11, p. 538.

112 Ibid. p. 539.

113 Straumann, 'Right to punish', pp. 5, 9.
} 
that 'by the strict law of nature no one is bound by another's act,' and immediately takes the precise opposite position on corporate liability from the one he had advanced in De Indis: 'The debt of the corporation, moreover, is not a debt of the individuals, as Ulpian well declares, especially if the corporation has property; for the rest the members of a corporation are not bound as individuals, but as a part of the corporate body.'114 Collective liability for debts has been introduced by the law of nations 'because otherwise a great license to cause injury would arise; the reason is that in many cases the goods of rulers cannot so easily be seized as those of private persons.' Grotius returns to the analogy of a surety: 'this principle ... is not so in conflict with nature that it could not have been introduced by custom and tacit consent, since sureties are bound without any cause, merely by their consent.'115 In fact, Grotius later argues, the right to seek reparation from all citizens based on this collective fiction is of a uniquely strong kind: 'This right of the law of nations, indeed, we hold to be of another kind than that which exists in mere impunity or the external power of courts of law ... a right is acquired by a kind of common consent, which through a certain force contains in itself the consent of individuals, in the sense in which a law is called "a common agreement of the state". This right was approved by nations 'not only for the sake of avoiding greater evil but also to secure to each one his right.'116

The effects of Grotius's separation of subjects from sovereigns is even more pronounced in his description of the law of nations respecting public war. In general, Grotius set very few enforceable, absolute obligations on belligerents. Just one chapter of the work describes limitations placed on belligerent conduct by the law of nature, primarily addressing when it is permissible to lie to an enemy. ${ }^{117}$ Instead, Grotius acknowledged that the law of nations gave combatants a very wide sweep of permissions, including a massive expansion of permissible targeting and acquisition in public wars-far beyond anything the Scholastic tradition would have accepted.

Grotius lays down two conditions which are unique to properly declared public wars. First, Grotius distinguishes two senses of the 'permissibility' of acts in war-acts which are 'right from every point of view and ... free from reproach, even if there is something else which might more honorably be done,' and acts which 'among men [are] not liable to punishment.'118 This latter sense

\footnotetext{
114 IBP, III.2.1, p. 623.

115 IBP, III.2.2, p. 624.

116 IBP, III.13.1, p. 757.

117 IBP, III.1.

118 IBP, III.4.2, pp. 641-42.
} 
covers 'the effects of a public war,' insofar as the law of nations is more permissive than the law of nature: 'it is permitted to harm an enemy, both in his person and in his property.119 Second, Grotius claims that the law of nations has introduced a principle that all acts by both sides in a public war will be accorded the effects of lawful acts by neutral nations; 'it has seemed altogether preferable to leave decisions in regard to such matters to the scruples of the belligerents rather than to have recourse to the judgments of others. ${ }^{\prime 20}$ Neutral nations have to respect the transfer of property by capture in warfare without regard to the justice of the cause, and most importantly, cannot punish a belligerent for actions taken in a public war, which would otherwise constitute theft or murder on the part of an unjust belligerent. ${ }^{121}$

Guided by these principles, Grotius then addressed the specific permissions nations have agreed to grant under the law of nations. Their content is startling: it is permissible to kill anyone in enemy territory, including women and children, prisoners, those who attempt to surrender, and hostages. ${ }^{122}$ Even foreigners in enemy territory, the test case for the argument that those who are not part of a civil society are not liable to punishment, may be killed. ${ }^{123}$ The permission to kill any member of an enemy society likewise entails the lesser permissions to confiscate or destroy all of their property and to enslave them, as well as to take over the civil power of a nation. ${ }^{124}$ Yet Grotius acknowledged that these permissions conflicted with his arguments about the sharing of punishment. In assessing what could be done to the persons of enemies in war, he reaffirmed that 'retaliation that is lawful, and properly so called, must be inflicted upon the very person who has done wrong, as may be seen from what has previously been said on the sharing of punishment,' while by contrast in war 'what is called retaliation very frequently brings harm to those who are in no way to blame for that on which the issue is joined.' ${ }^{125}$

The consequence of these claims was that almost all of Grotius's arguments about who could legitimately share responsibility for the state's acts were shifted to the realm of 'moral justice,' part of Grotius's pleas for moderation in war.

\footnotetext{
119 IBP, III.4.3, pp. $643-44$.

120 IBP, III.4.4, p. 644.

121 IBP, III.4.3, pp. $643-44$.

122 IBP, III.4.9-12, pp. 648-50; IBP, III.4.14, p. 651. On the relationship between these claims and Grotius's views on natural law, see Steven Forde, 'Hugo Grotius on Ethics and War', The American Political Science Review 92 (1998), pp. 639-48; Brian Tierney, Liberty and Law (Washington: Catholic University Press, 2014), pp. 236-47.

123 IBP, III.4.6-7, p. 646.

124 IBP, III.5.1, p. 658; III.7.1, pp. 690-91; III.8, pp. 697-700.

125 IBP, III.4.13, pp. 650-51.
} 
Once again, Grotius was careful to split his treatment along the axes of life and property. Only those who 'have done wrong, in a matter punishable with the penalty of death' should be killed in war, though Grotius does not go into detail because 'what needs to be known has been sufficiently set forth in the chapter on punishments.'126 Those who are compelled to serve should be spared, since they lack 'hostile intent,'127 and 'we must distinguish between those who are responsible for a war and those who followed the leadership of others.'128 Morality often encourages even remitting punishment of those responsible for a war. ${ }^{129}$ Similarly, prisoners of war should not be executed for misdeeds by the other side in war, because " $\mathrm{i}] \mathrm{t}$ is not sufficient that by a sort of fiction the enemy may be conceived as forming a single body; this may be understood from our foregoing discussion on the sharing of punishments. ${ }^{\prime 130}$ With respect to property, however, Grotius returned to the surety analogy he had laid out in his discussion of punishment. The property of an enemy's subjects could legitimately be taken up to the cost of the original debt and any expenses incurred in the war, because 'according to the accepted law of nations, [a subject] is made liable, as though in the case of a surety.'131 Yet here Grotius went further; not only did the law of nature not permit confiscation of subject property as a punishment, but Grotius did 'not see that by agreement of the nations such a right has been extended to the property of subjects.' ${ }^{132}$ As a result, 'only those who have themselves done wrong,' such as magistrates, face loss of property as a punishment, even under the permissions of the law of nations. ${ }^{133}$

By this point, the payoffs of Grotius's strategy should be clear. While his thin conception of the state eliminated the categorical protections women and children received under the natural law in the Scholastic writers, it also eliminated the natural law requirement that combatants must be subject to punishment for their acts in pursuing an unjust war. In fact, legitimate claims to guilt were limited to only a small subset of individuals who actually govern the state. This point carried Grotius much further along the path toward restraining war by moral means than the natural law requirements put forward by the Scholastics, and without the potentially dangerous consequence of

\footnotetext{
126 IBP, III.11.2, p. 723.

127 IBP, III.11.3, p. 724.

128 IBP, III.11.5, p. 729.

129 IBP, III.11.7, pp. 731-33.

130 IBP, III.11.16, p. 741.

131 IBP, III.xiii.1, p. 757.

132 IBP, III.xiii.2, p. $75^{8}$.

133 Ibid.
} 
encouraging punitive wars against those who persistently violated the dictates of the law of nature with respect to war. Of course, this latter point was only necessary because Grotius continued to insist on a persistent individual right to punish.

In fact, one of the most significant consequences of Grotius's mode of reasoning was that it enabled him to preserve a very wide sweep of private action. This point remained important for Grotius and the Dutch more generally, as the VOC and commissioned privateers played a uniquely important military role in the Dutch revolt. ${ }^{134}$ Grotius's refusal to fully vest punitive or warmaking authority in the sovereign as a matter of natural law opened the door for a broad justification of such private action and substantial participation in public wars by private actors. This, too, ran headlong into prevailing accounts of the laws of war. As Gentili described it, the essential difference between a pirate and a privateer was public authorization: 'The claim to the title of general will be justified, not so much by the command of a regular army or by the capture of cities ... as by the assumption of a public cause. ${ }^{135}$ This distinction had critical implications for the legitimacy of captures. On the basis of Roman law, for example, it was generally held that unauthorized actors (like pirates) did not have the right to postliminium and could not legitimately transfer title by capture, ${ }^{136}$ and Suarez emphasized that 'soldiers are not allowed to seize anything on their own authority, whether after or even before victory is won; because they have in themselves no power, but possess it solely through their prince, as his agents, so that they may not justly take anything without his express or implied authorization.'137 It also played a key role in determining whether the laws of war applied in a given conflict. Those who act without

134 As van Ittersum has shown, Grotius's interest in voc affairs and European activities abroad persisted through his exile and the writing of De iure belli. Van Ittersum, 'The Long Goodbye: Hugo Grotius' Justification of Dutch Expansion Overseas', History of European Ideas 36 (2010), 386-411. On the disproportionate reliance of the Dutch on privateering, see Ivo van Loo, 'For Freedom and Fortune: The Rise of Dutch Privateering in the First Half of the Dutch Revolt, 1568-1609', in: Exercise of Arms: Warfare in the Netherlands 1568-1648, ed. by Marco van der Hoeven (New York: Brill, 1997), pp. 174-78; Jan den Tex, Oldenbarnevelt, trans. R.B. Powell, 2 vols. (New York: Cambridge University Press, 1973), I, pp. 282, 304. On Dutch privateering both before and after the era of Grotius, see Virginia Lunsford, Piracy and Privateering in the Golden Age Netherlands (New York: Palgrave MacMillan, 2005).

135 Gentili, Three Books on the Law of War, I.4, p. 24.

136 See, e.g., Suarez, 'On Charity', § 7, p. 842; Gentili, Three Books on the Law of War, III.23, p. 423.

137 Suarez, 'On Charity', § 7, p. 840. 
public authorization - notably including, in Gentili's account, rebels-are outside the protection of the laws of war. ${ }^{138}$ On this basis, Gentili condemned the fact that the Spanish did not treat 'as lawful enemies' some captured Frenchmen in the service of Don Antonio, a claimant to the throne of Portugal in the 1580 s, because 'letters of their king which they exhibited' showed that they were authorized by the French crown. ${ }^{139}$

Grotius, by contrast, claims that there is no natural law restriction on what individuals can do as part of a public war, and continues to argue that by natural law individuals can engage in a range of violent activities absent state authorization. We have already seen Grotius's willingness to permit individuals to continue to engage in punishment in the absence of state jurisdiction, and he takes a similar position with respect to the continued viability of legitimate reprisal. The only restrictions on who may exercise this right, Grotius suggests, are set by municipal law: 'by the law of nations individuals possess the right of taking sureties, as at Athens, in the seizure of men. By the municipal law of many countries this right is sought in some cases from the supreme authority, in other cases from judges.' Similarly, the bare act of seizure is sufficient under the law of nations to legitimately transfer ownership of property in reprisals; no intervention from the captor's state is required. ${ }^{140}$ The wrinkle in this claim is that individuals can still take action to satisfy their private debts while viewing all members of their debtor's society as liable for the debt; this appears to be the source of Grotius's claim that this right persists by virtue of the law of nations and not the law of nature.

Along the same lines, Grotius argued that because the law of nations declares 'that the property of enemies should stand to enemies in the same relation as ownerless property,'141 private individuals, acting without sovereign authorization, can legitimately acquire enemy property. Goods 'taken outside of the public service' are owned by the individuals who take them, such as 'spoils seized by soldiers in free and unauthorized raids at a distance from the army.'142 Grotius doubled down on this line of reasoning in a short chapter late

\footnotetext{
138 Gentili, Three Books on the Law of War, I.4, pp. 22-25.

139 IBP, I.4, p. 26. As Alfred Rubin has noted, this position massively strengthened the hand of sovereigns: 'each "sovereign" would seem to be accorded the legal power, by "recognizing" anybody's legal status needed to license privateers or naval commanders ... to determine what legal regime would be applied to any struggle between the "sovereign" and an enemy of uncertain status.' Alfred Rubin, The Law of Piracy (Newport, RI: Naval War College Press, 1988), p. 21.

140 IBP, III.2.7, p. 629.

141 IBP, III.6.8, p. 670 .

142 IBP, III.6.12, pp. $672-73$.
} 
in Book III, 'On Acts Done by Individuals in a Public War.' Grotius began by discussing a passage in Cicero's De officiis which was generally taken to demonstrate the necessity of sovereign authorization to participate in public war. In the passage, Cicero relates a story about the elder Cato in which he wrote a letter to his son, who had been mustered out of the military, in which the warns the youth to avoid engaging in battle, for the reason that it is not right for one who is not a soldier to fight with an enemy.'143 Grotius contends that this obligation cannot proceed from the law of nations, since 'enemies are held to be entitled to no consideration.' The law of nations imposes no duties with respect to enemies, so enemies certainly cannot complain that an unlicensed individual has attacked them; consequently, 'the advice of Cato ... comes from Roman military discipline.'144 Grotius contends that this institution of Roman law does not reflect anything about the natural law: If, however, we regard the law of nature and moral justice, it is apparent that in a lawful war any person is allowed to do whatever he trusts will be of advantage to the innocent party, provided he keeps within the proper limits of warfare.'145 The critical conclusion is that 'those who support a part of the war with their own expenditures, such as those who fit out and maintain ships at private cost,' are entitled to participate in combat. ${ }^{146}$ Indeed, these combatants can develop independent causes for war separate from those of their state. ${ }^{147}$ The connecting thread is Grotius's repeated insistence that the law of nature does not require sovereign control over violence. In principle, it appears such violence could include engaging in punishment on the state's behalf, so long as that punishment was 'within the proper limits of warfare.' Indeed, he states that they might be able to retain captured property if they are 'enforcing a legal penalty according to the common law of mankind,' ${ }^{148}$ suggesting that punishment is a permissible justification for private actions in war.

\section{Conclusion}

Grotius's famous innovation - the private right of punishment - touched off a series of re-evaluations of core aspects of the tradition of sovereignty and just

\footnotetext{
143 IBP, III.18.1, p. 788.

144 Ibid.

145 Ibid. p. 789 .

146 IBP, III.18.2, p. 789 .

147 IBP, III.18.5, p. 791.

148 IBP, III.18.1, p. 789 .
} 
war theory which he inherited. The specific goals of De Indis, rooted as they were in the justification of a particular case and the corresponding need to explain the voc's unique role in the Dutch revolt, invited modifications to the Scholastic theory of sovereignty. These modifications enabled Grotius to vindicate the voc's acts as a legitimate exercise of private warmaking authority while also appropriating Scholastic arguments about collective responsibility. Appropriation of these positions also allowed Grotius to turn Scholastic arguments into a justification of the Dutch revolt as a public war.

By the time of De iure belliac pacis, however, Grotius had a wider view. Many of his broader objectives remained the same: preserving a role for the voc and defending Dutch sovereignty were no less important than at the time of De Indis. Yet Grotius found in his novel approach to sovereign power a way of accommodating these objectives alongside his new effort to introduce humane practices in war. Rejecting the Scholastic vision of the powers necessary for a complete state, even as modified by the transfer theory proposed in $D e$ Indis, significantly shrank the natural law implications of the compact creating sovereignty. For one, it severed the agency relationship between subjects and sovereigns that had been central to much previous thought on sovereigntyand, by extension, to accounts of the laws of war-permitting Grotius to minimize justifiable targeting and confiscation in warfare as a matter of natural law. This shift also gave Grotius additional room to argue that certain rights, most significantly the right to punish, were not by nature exclusively held by the sovereign. Instead, he referred all such questions to the particular consensual arrangements of each society - a key argument for justifying the Dutch revolt. Yet he was never precise about what the 'subjection' of individuals to the state through that contract entailed, as his discussion of the various rights of punishment demonstrates.

Grotius's peculiar combination of objectives was not shared by later writers, in particular his desire to protect private warfare. Indeed, Jean Barbeyrac, in his commentary on the text, sharply criticized precisely the features of De iure belli ac pacis which were at the core of Grotius's reappraisal of sovereignty. On reprisal, for example, he insisted that 'the End of civil Society requires, that private Persons should not make use of this Right, but with the Permission, either express or tacit, of the Sovereign,' 149 a claim he repeated when addressing

149 Barbeyrac's comments are most accessible in Hugo Grotius, The Rights of War and Peace, trans. John Morrice, ed. Richard Tuck (Indianapolis: Liberty Fund, 2005), iii.2.7 n. 2, p. 1244 . 
Grotius's views on private participation in public wars. ${ }^{150}$ Yet Barbeyrac's critique rested on the precise claims about sovereignty absent from Grotius's account: 'the Law of Nature ... requires ... that in a thing of so great Importance [participating in war], which relates to one of the principal Parts of Sovereignty, nothing should be done without the particular or general Permission of the Sovereign, or his ministers; since that is a necessary consequence of the Engagement of a Subject, considered as such.'151 This line of argument also undermined the moderation Grotius contended was required under the law of nature, because it depended on the idea that under the law of nature 'every Individual may be deemed to be engaged to answer for what the Society, or Powers which govern it, do, or owe, ${ }^{152}$ a claim Barbeyrac extends to punishment. ${ }^{153}$ As his unique conception of sovereign power attests, nothing could be more antithetical to Grotius's goals in De iure belli ac pacis. ${ }^{154}$

150 See Grotius, Rights of War and Peace, iii.6.10 n. 1, p. 1330 (capture of enemy property cannot take place without permission from the sovereign); Grotius, Rights of War and Peace, III.18.1 n. 10, p. 1529 (rejecting the argument 'that in Civil Society a private Person can act against the Enemy without the express or tacit order of those, who are invested with the publick Authority').

$15^{1}$ Grotius, Rights of War and Peace, III.18.1 n. 10, p. $15^{29}$.

$15^{2}$ Grotius, Rights of War and Peace, III.2.2 n. 1, p. 1233.

153 Grotius, Rights of War and Peace, III.13.2 n. 1, p. 1476.

154 I would like to thank Charles Donahue, Eric Nelson, and Richard Tuck for helpful conversations and comments as this paper developed, as well as Theo Christov and other participants in a panel discussion at the 2015 Midwest Political Science Association conference for comments on an earlier draft. The paper also benefited from extremely valuable critiques by an anonymous reviewer for Grotiana. Finally, thanks are due to Mark Somos and the staff of Grotiana for their help and patience. All errors and shortcomings, of course, remain wholly my own. 